\title{
Tourism as Empowerment: Women Artisan's Experiences in Central Mexico
}

\author{
Paola Vizcaino Suárez \\ Facultad de Turismo y Gastronomía \\ Universidad Autónoma del Estado de México \\ Mexico \\ paola.vizcaino.suarez@gmail.com
}

\section{Introduction}

In the past decade, feminist scholars in Mexico have added to the research on gender and tourism by focusing on the impacts of tourism development in host communities and discrimination patterns in tourism employment. A handful of these studies have examined tourism's potential to promote gender equality and women's empowerment (e.g. Fernández and Martínez, 2010; Díaz-Carrión, 2012; Mendoza and Chapulín, 2015). The subfield has advanced the critical analysis of gender and work, exploring a) how the meanings of masculinity and femininity circumscribe the ways in which women get involved in tourism, and b) how the continuous interaction with tourism processes may contribute to the modification of gender definitions (Swain, 1995), opening productive and social opportunities for women.

This chapter seeks to contribute to the debate on tourism as empowerment, through the exploration of the life stories of two urban mestiza women who work as producers and vendors of handicraft pottery catered to domestic and international visitors in the "Magical Town" of Metepec, in central Mexico. As discussed in the book's introduction, the feminist approach to empowerment includes "power to" and "power from within" and involves "undoing negative social constructions, so that people come to see themselves as having the capacity and the right to act and influence decisions" (Rowlands, 1997, p. 14). The women in the case study assess local gender roles in a patriarchal society and challenge the entrenched belief that only men can be artisans or lead a pottery workshop. The analysis of the broader socioeconomic context in which the research participants live and work, facilitates the understanding of structures, policies and gender-power relations that enable or limit women's agency (Kabeer, 1999).

The data for the life stories come from the ethnographic research conducted for my $\mathrm{PhD}$ thesis, in which Delfina and Edna were key respondents (the names have been changed to maintain confidentiality). A variety of methods consistent with a feminist interpretive methodology were employed, including formal and informal interviews, participant observation and document analysis during nine months of fieldwork in 2014 and 2015. The narratives were translated from Spanish into English. The aim is not to generalize the life stories in question but to examine the ways in which women make sense of their gendered interactions with tourism and the possibilities for empowerment. 


\section{Gender and tourism in the Mexican context}

Gender encompasses crucial aspects in the lives of women and men; including activities and creations, perceptions of the self, material and symbolic assets, power, and sense of individual limits (Lagarde, 1996, pp. 13-14). The construction of gender roles and stereotypes in Mexico, has historically characterised men as heads of household and breadwinners (conceived as productive work in the public sphere); whereas women have been assigned care and domestic chores (conceived as reproductive work in the private sphere). The ideology of machismo emerged from the Mexican Revolution at the beginning of the $20^{\text {th }}$ century and contributed to the exaltation of virility expressed by indifference to danger, the disparagement of feminine virtues and the affirmation of authority by men from the subaltern classes (Monsiváis, 1981).

The macrostructural adjustments promoted by neoliberal policies in Latin America, the deterioration of working conditions, increased social vulnerability and poverty levels, along with profound demographic and sociocultural transformations, have modified traditional family arrangements of male breadwinners and female housewives. Through their massive incorporation into the labour market and economic contributions to their families, women have increased their presence in the productive and public realms, redefining their role in society (Carosio, 2012). However, reproductive work has been less prone to experience change, with women bearing the burden of care and domestic responsibilities (Arriagada, 2004).

The increased participation of women in the labour market can be observed in Mexico's tourism industry, where women represent over $57 \%$ of the total labour force and $45 \%$ of the workers in tourism-related sectors (calculated from INEGI, 2015). The tourismrelated sectors include the production and sale of handicrafts and food in tourist destinations. Women also participate in the informal sector as vendors in international coastal resorts (Gámez et al., 2011) and small or medium-sized cities involved in cultural tourism (Bayona, 2013). Employment opportunities in tourism are largely based on the sexual division of labour, limiting the types of jobs available for women (horizontal segregation) and relegating them to occupations with lower pay and status (vertical segregation) (SECTUR-COLMEX, 2011). Despite market limitations, tourism processes in Mexico have opened spaces for women to redefine their identities, learn new skills, obtain financial autonomy and establish social and business networks (Fernández and Martínez, 2010; Díaz-Carrión, 2012; Fierro et al., 2014), which can support the contestation of unequal gender relations.

\section{The "Magical Town" of Metepec}

Metepec is an internationally renowned pottery production centre in the State of Mexico, located next to the state capital of Toluca and $47 \mathrm{~km}$ southwest of Mexico City. The pottery tradition dates back to pre-Hispanic times and adopted new manufacturing techniques under the Spanish influence during the colonial period (Schneider, 2001). Until the 1960s, pottery production in Metepec focused on ritual and utilitarian purposes that satisfied the demand of local families. Production has shifted in the past 50 years 
to decorative and aesthetic purposes, to satisfy the growing demand of tourism markets (McAllister, 2001; Hernández and Zafra, 2005).

Figure 1. Pottery shops at the Metepec Handicrafts Market. Source: Author's personal file.

The preservation of traditions and festivities in its historical quarters, gained Metepec a coveted place in the national "Magical Towns" programme in 2012. The programme has increased municipal, state and federal funding for tourism infrastructure and promotion. The main infrastructure project for the period 2014-2015 was the rehabilitation of the handicrafts market, built in the late-90s with the purpose of providing a space for artisan families to sell their production directly to the public.

In both Metepec's pottery workshops and wider community, dominant gender norms and ideologies assign different activities, spaces and value to the work performed by women and men. Power imbalances are also evident in community organizations where leadership positions continue to be predominantly occupied by men. Despite being at the margins of local power systems, the two life stories illustrate how women negotiate gender roles and define strategies to take advantage of tourism transformations with the resources available to them.

\section{Women artisans experiences in Metepec}

\section{Negotiating gender, work and identity}

In Metepec's patrilineal system, the social status as artisan is ascribed to the male heads of household (Schneider, 2001). This is consistent with patrilineal traditions in other pottery towns in central Mexico (Moctezuma, 2012). Artisans in Metepec rationalise the sexual division of labour within the family workshops due to the physical demands of some tasks involved in pottery production. Men undertake processes that require more physical strength (preparing the clay mix, sculpting large objects, firing), while women specialise in tasks that require dexterity (sculpting smaller objects or "miniature", painting or decorating the finished pieces).

Delfina (50) has worked as producer of decorative handicrafts for 30 years, yet finds it difficult to recognise herself as an artisan:

\footnotetext{
When you asked me if I was an artisan, I answered that I am not, because my parents weren't artisans, my family didn't have that tradition... so in this market... people point at you and say: 'You are not an artisan'. You may do all the creative work, but you are not considered an artisan.
}

Edna (35) more readily embraces her identity as artisan, perhaps because she's younger and she did not grow up in Metepec. She got involved with handicraft pottery through her marriage with an artisan assistant 15 years ago. Edna enjoyed observing her now ex-husband's work and started practicing the painting and sculpting techniques on her own: 
Nobody transmitted the knowledge to me, I didn't inherit it... But I had to adapt and I learned to make all the process. From the beginning: from mixing the clay, sculpting it, drying it, firing it and then painting it, until obtaining my own customers... Yes, I consider myself an artisan.

Edna's account shows how women can contest gender norms through agency. But women's agency does not always manifest as contestation, it can take the form of more subtle negotiations (Kabeer, 1999). In my research, married women were more likely to express support for the sexual division of labour in pottery production, if this meant avoiding activities they didn't enjoy. Delfina's description of the "heavy work" required to prepare the clay mix illustrates this point:

It is heavy work, because you see, they bring you a big block of clay, it can weigh up to $5 \mathrm{~kg}$, it depends. You have to grind that block of clay with a stone roller that may weigh some $70-80 \mathrm{~kg}$. So for a woman -and yes, there are women who do this work- for a woman, it is heavy work because you lay down some 2 or 3 wheelbarrows of clay and you have to crush the clay with the roller over 100 times, until you obtain a thin sand or powder...This work is done by my husband. I know how to do it, but since it is heavy work, I avoid doing it. I take the prepared mix from my husband to sculpt my objects.

Unlike 50 years ago, artisans do not have to collect clay from the nearby hills, nor carry big blocks that require heavy lifting, nor pulverise those blocks into the dust required for the clay mix. Even though male artisans continue to perform some of these activities, there are several alternatives to the clay preparation process that are readily adopted by women who lead their own workshops, like Edna:

Since I don't even have room to store big clay blocks, I buy sacks of ground clay. They previously grind, clean and sieve the clay. So I simply add water and plumilla [a kind of reed flower found in the few remaining wetlands of Metepec] to make the mix.

The alternatives to the physically demanding processes traditionally deemed as men's work, have opened opportunities for Edna and other women to start their own handicraft pottery production. This has contributed to women challenging the belief that pottery is reserved to men. Another perception that women are beginning to challenge is that of men being the primary breadwinners (Lagarde, 2004), as exemplified in Delfina's reflection:

There is still the belief that men are the breadwinners. I mean, it is losing strength because nowadays we all participate in the production, but we still think that it is the men who do the heavy work.

Gender inequalities within the private realm are most persistent when it comes to the distribution of housework, as confirmed by research on social change and continuity in the context of Latin American families (Arriagada, 2004). Delfina explains:

Men usually do not do much housework. Maybe they heat up coffee or milk in the morning, but the real housework... no, no... We are still under machismo. In my case, my husband does help me a little [emphasis mine]. He deals with the yard and garden. He knows those are his tasks. While he is cleaning the yard, I prepare 
breakfast and put the clothes in the washer. Then we both take our youngest daughter to school.

While married women like Delfina undertake negotiations with partners to attempt a more equitable distribution of housework, women heads of household have to develop strategies to organise productive and reproductive work on their own (Rojas, 2016). Edna's experience illustrates this case. She separated from her husband a couple of years ago and has become the primary supporter for her children (aged 15 and 8), intertwining both types of work at home:

I work based on times. For example, I wake up at 6:00 am, help the kids get prepared for school. Come back home at 8:00 am and if I have orders, I get that work done, if not, I have time to clean up, make food and all. But then I pick up the kids from school, I feed them and then sit for another while to work [on handicrafts]. I check the kids' homework, make sure they have everything ready. I work more at night, from 10:00 pm to 1:00 am, more or less, depending on the orders. There are days when work decreases. Other days, I have work in excess.

To cope with the periods of "work in excess", Edna has incorporated women in her immediate social circle to help her with production, and in turn provides an opportunity for these women to gain an income. This is consistent with the notion of women strengthening links through the recognition of each other (Lagarde, 2004):

Three other women work in my workshop. I don't know if it's because of the difficulties I faced to start my workshop, I have offered other women the opportunity to work. For example, my neighbour has diabetes and it's difficult for her to find a job, because she gets sick, or she needs to go to the doctor... so... she helps me. I give her paint [to decorate handicrafts], she takes it to her apartment and she works there. My mother, since she became a widow, also helps me to paint and make small objects. And my 15 year old daughter helps me decorate handicrafts.

Even though individual women are negotiating their identity as artisans and gaining confidence in their productive capacities, their efforts are not always recognised by the larger community. There are cultural and institutional barriers that continue to limit women's advancement (Deere and León, 2002). This is illustrated in Delfina's account:

Local authorities usually promote the work of male artisans. Pottery artwork is usually commissioned to men from well-known families. Competitions are won by the same male artisans... I know a lot of women artisans who do excellent work but have little recognition because they don't have a well-known family name or because they don't have influence in the local government. So they start to fall behind.

There is a marked hierarchy within the artisan community in Metepec. Members of families who contributed to the internationalization of local pottery through the creation of monumental "Trees of life" hold a higher status, participate in international competitions and export their work abroad as signature artists (F. Pagés, Metepec, 2015, personal communication). Delfina provides an example of how local politics works in the handicrafts market: 
Here in the market we have five strong men. They go everywhere to demand aid and they exchange favours with the local officials. 'Here, you become the godfather of my child', or 'I will organise a meal for you'. So those five men are always working [the system]".

Very few actors gain from these type of arrangements, whereas a broad group of artisans who lack political networks (usually younger, poorer, female or from a different town) end up being excluded from key decision-making processes and other productive opportunities (e.g. training programmes, access to aid and credit, or participation in sale exhibits). Women producers feel particularly relegated due to gender discrimination, as exemplified by Edna's reflection:

If you do not belong to one of those [well-known] families, you are not taken seriously. Often times, they make you feel unwelcome and that you have nothing to do there... Maybe they thought that my husband was the one who worked with clay and not me... they couldn't believe that I did all the work - from preparing the clay to firing the objects. They are not used for women to do that.

The situation for women artisans improved with the introduction of gender-aware policies in the two administrations led by female majors during the periods 2009-2012 and 2012-2015. For the first time in decades, an open call was made for women to register in the municipal artisan census, where members receive information on public aid, training and competitions. A newly-appointed young female official was assigned the responsibility to follow up on the needs of women artisans, as Edna recalls:

Before, it was the male municipal officials from the Handicrafts Promotion area that did not let me show my work or anything. But the new female official made sure women producers could register in the census, just as men always have. Currently, I am in the census and I have an ID. Now I can prove that I'm an artisan too [laughs].

\section{Taking advantage of tourism transformations}

Despite being at the margins of the local power system, Delfina and Edna have taken advantage of the material and symbolic transformations brought by tourism development in Metepec. One of the material transformations that had the most impact on artisan families was the creation of commercial tourist places like the handicrafts market, where over 50 families sell their pottery directly to visitors, tourists and wholesalers. The market has changed women's daily routines and provided a new space for productive work and socialising. Positive changes in women's lives (e.g. increased self-esteem and strengthening of social networks) have also been documented in community-based tourism projects; whereas negative changes refer to increased workload and less free time (Rodríguez and Acevedo, 2015). Before the creation of the market, women worked at home mostly on domestic and caring responsibilities as well as activities related to handicrafts production or other sources of income. Delfina recalls:

I used to paint and sculpt at home. Well, I had my time to be with my children, but I also did other things. I sold gold, shoes, clothes...depending on the season. But 
even then, I did my housework. When the market started, then we had to divide our time and come here. But I think most women used to work at home before the market.

For Delfina, working an 8-hour shift everyday has meant family disunion, because women no longer spend most of the time with their children. But the market has opened new sources of income for women, as Delfina explains:

We can sell in the market and then my husband sells at the workshop, so not only my husband brings in money, there's another source of income.

In contrast, Edna continues to work from home and does not sell directly to tourists, but the demand for her handicrafts significantly depends on the tourist market: "I don't sell directly to tourists, but I take my work to 6 shops in the handicrafts market." Edna appreciates the flexibility of working from home at her own pace and not having to open a handicrafts shop during fixed hours:

I'm always working, even on weekends, so when I have some free time I like going to family reunions and social events ... and yes, we like to go out a lot, since we are from Tenancingo [a nearby town]... we like to go there and rest a bit. If I had a shop, I would have to stay every weekend, which is when most visitors come.

Both women have obtained financial autonomy through their work as producers of handicraft pottery and tourism has contributed to opening new markets for their work. This is consistent with the experience of female artisans in other parts of the country (Rojas-Serrano et al., 2010; Fierro et al., 2014). Despite the literature's emphasis on women's economic empowerment (Tucker and Boonabaana, 2012), the experiences of women in Metepec show an appreciation for psychological empowerment. Some of the symbolic transformations brought by tourism development stem from women socialising with people outside their family networks (other artisans, tourists, local authorities). This has contributed to the redefinition of women's identities, and in some cases, the recognition of their work by outsiders. For example, Delfina expressed experiencing a sense of personal growth through her interactions with visitors in the handicrafts market:

I have met a lot of people from whom I have learned a lot... one grows as a person. You grow in the sense that you are not only at home watching soap operas. You are in a business, serving people, meeting people, doing what you like and making money, what else can you ask for?

Edna values the community recognition she has obtained from participating in handicraft competitions. She won her first award a few years ago at the Quimera Cultural Festival in Metepec, which receives thousands of visitors annually in October:

I felt a great emotion, like receiving... I don't know... like when I finished High School... that is, another accomplishment. It is like saying: 'I was able to do it'. Because when you receive the award, they call you maestra. And there is a huge change in how people see you. 
Women are also weighing the positive and negative aspects of Metepec's incorporation into the "Magical Towns" programme, as illustrated in Delfina's account:

I think it's great that we are a Magical Town. This is attracting more visitors, mainly from other parts of the country...There are people who come saying: 'We came because we heard Metepec is a Magical Town and it looks really nice'. But something negative is that we are being forced to pay more taxes.

\section{Defining power and empowerment}

Throughout our conversations, Delfina and Edna reflected on personal, family and institutional barriers they have encountered as women artisans in Metepec. They were able to articulate ways in which they had overcome some of those barriers through what feminists understand as "power for" and "power from within" (Rowlands, 1997). The interconnections between tourism and culture have opened spaces for negotiating power (Serrano-Barquín, 2008) through a process of learning and creating, as evidenced in the participants' narratives.

Edna defines "power for" as the capacity to create handicraft pottery, from beginning to end. The "power from within" is her perseverance to support her family after separating from her husband and provide work for other women in a vulnerable situation. These definitions are illustrated in her account:

The first challenge, was to demonstrate that I could do the work. To confront the men, because I tell you that men -I don't know if it's because of the physical strength required to knead the clay or to carry large objects- they think a woman is not enough for that. But yes, they questioned how I could do it: 'How could she? How?' The first challenge was that. And then, as a woman, to demonstrate myself that I could support my family, my children... Another challenge was to have people help me [with production] and being able to pay them. Because, that isn't easy. I mean, it is easy to say: 'Yes, come help me and I will see how much I can give you'. No, a fair salary for their work. And then, the recognition that I obtain as a woman, by demonstrating I can do all the production process.

Delfina also defines "power for" as her capacity to create handicraft pottery. The "power from within" refers to overcoming her fears and gaining self-confidence:

Look, I have an economy, not a very good economy, but I have my income. I have a family, which is not always supportive of my work, but I have one. In my work, I have done what I've wanted. When it comes to meeting people, I think I have a treasure there. I know a lot of people: very humble, middle class and rich people...Before, I used to have a lot of fear, but I have read a lot, that fear limits you and makes you useless. So now, with that fear, I give myself strength... and I take a step forward. Being here in the market for 17 years has opened a lot of doors. I have learned many things.

As for their plans for the future, Delfina wants to continue working in the market and becoming more active in community organisations, while Edna wants to have 
a bigger workshop in a central location, where she can work, exhibit her handicrafts and sell to the public.

\section{Conclusion}

The cases presented highlight how tourism can open productive and socialising opportunities for women, contributing to their economic and psychological empowerment. The life stories illustrate how women engage in negotiations to redefine gender, work and identity, challenging the entrenched belief that only men can be artisans or lead pottery workshops. Women's interactions with people beyond their family networks (e.g. tourists, other artisans and local authorities) have generated spaces for the recognition of their work as producers and vendors of handicraft pottery, increasing their self-esteem and sense of accomplishment.

The stories also show how women experience politics in the everyday life (Lagarde, 2004). The family level is crucial for negotiating changes towards more equitable gender relations and redistribution of care and domestic work traditionally assigned to women. But broader social and institutional support is required to produce transformations at the community level. Despite women's individual efforts, the work of male artisans continues to be regarded in a higher esteem, and the leadership positions within the artisan community continue to be occupied by men. There is a dynamic of exclusion around women's participation in decision-making processes, which is reinforced by the lack of institutionalisation of gender-sensitive policies at the local level. The efforts started by the two female majors have stalled under a new maledominated administration.

Furthermore, despite legal and policy frameworks that call for the promotion of gender equality and women's empowerment in Mexico's tourism planning, these goals have not been implemented in existing programmes (Vizcaino-Suárez et al., 2014), such as the national "Magical Towns Programme". To transform regulative ideals into tangible efforts, it is necessary to bring women's voices to the forefront of national and local policy debates. Tourism research with a gender perspective can contribute to identifying pathways for empowerment from individual and everyday standpoints (Bergareche and Vargas, 2010). Policy can focus on supporting what women are already doing to produce change in their lives, and advance strategies to dismantle the structural barriers that limit women's agency and exclude them from decision-making processes. Policy should also contribute to provide public alternatives to private arrangements for care and domestic work, since women continue to carry the burden of these responsibilities on top of their income-generating activities in tourism and other sectors.

\section{References}


Arriagada, I. (2004) Transformaciones sociales y demográficas de las familias latinoamericanas. Papeles de población 10(40), 71-95.

Bayona, E. (2013) Textiles para turistas: tejedoras y comerciantes en los Altos de Chiapas. PASOS. Revista de Turismo y Patrimonio Cultural 11(2), 371-386.

Bergareche, A. and Vargas, E. (2010). Nuevos desafíos, renovadas miradas: algunas propuestas al debate sobre género, desarrollo y turismo en el Pacífico mexicano. México y la Cuenca del Pacífico 13(37), 75-102.

Carosio, A. (2012) Presentación. In: Carosio, A. (ed.) Feminismo y cambio social en América Latina y el Caribe, $1^{\underline{a}}$ ed. CLACSO, Buenos Aires, Argentina, pp. 9-17.

Díaz-Carrión, I.A. (2012) Turismo de aventura y participación de las mujeres en Jalcomulco. PASOS. Revista de Turismo y Patrimonio Cultural 10(5), 531-542.

Deere, D.C. and León, M. (2002) Género, propiedad y empoderamiento: tierra, Estado y mercado en América Latina. Universidad Nacional Autónoma de México - FLACSO, Mexico City, Mexico.

Fernández Aldecua, M.J. and Martínez Barón, L.A. (2010). Participación de las mujeres en las empresas turísticas privadas y comunitarias de Bahías de Huatulco, México. ¿Hacia un cambio en el rol de género?. Cuadernos de Turismo 26, 129-151.

Fierro Reyes, I. G., García de Fuentes, A. and Marín Guardado, G. (2014). Turismo de hacienda, trabajo femenino y transformaciones locales: El caso de los talleres artesanales de la Fundación Haciendas del Mundo Maya. Península 9(1), 105-125.

Gámez, A.E., Ivanova, A. and Wilson, T.D. (2011) Género y comercio informal en destinos turísticos. El caso de las vendedoras de playa en Los Cabos, Baja California Sur, México. TURyDES: Revista Turismo y Desarrollo Local 4(9), 1-31.

Hernández, J. and Zafra, G. (2005). Artesanas y artesanos: creación, innovación y tradición en la producción de artesanías. Plaza y Valdés, Mexico City, Mexico.

INEGI (2015) Encuesta Nacional de Ocupación y Empleo. Available at: http://www.inegi.org.mx/est/contenidos/Proyectos/encuestas/hogares/regulares/enoe/ (accessed 10 October 2016).

Kabeer, N. (1999) Resources, agency, achievements: Reflections on the measurement of women's empowerment. Development and change 30(3), 435-464.

Lagarde, M. (1996) Género y feminismo. Desarrollo humano y democracia. Horas y Horas, Madrid, Spain.

Lagarde, M. (2004) Vías para el empoderamiento de las mujeres. Available at: http://www.femeval.es/proyectos/ProyectosAnteriores/Sinnovaciontecnologia/Documen ts/ACCION3_cuaderno1.pdf (accessed 10 May 2017). 
McAllister, L. (2001) Suave misticismo del barro. Artes de México 30, 47-53.

Mendoza Ontiveros, M.M. and Chapulín Carrillo, J. (2015) Turismo, trabajo femenino y empoderamiento de las mujeres en Bahías de Huatulco, Oaxaca, México. Estudios y Perspectivas en Turismo 24(2), 316-335.

Moctezuma Yano, P. (2012) Familia patriarcal y trabajo artesano: Una forma organizativa laboral sustentada en el parentesco. Revista de estudios de género: La Ventana 4(36), 134-177.

Monsiváis, C. (1981). ¿Pero hubo alguna vez once mil machos? Fem 5(18), 9-20.

Rodríguez, G. and Acevedo, A. (2015) Cambios en la vida cotidiana de las mujeres a través de la incorporación al trabajo turístico en la Reserva de la Biosfera de la Mariposa Monarca. El Periplo Sustentable [Online] 29.

Rojas, O.L. (2016). Mujeres, hombres y vida familiar en México. Persistencia de la inequidad de género anclada en la desigualdad social. Revista Interdisciplinaria de Estudios de Género 2(3), 73-101.

Rojas-Serrano, C., Martínez Corona, B., Ocampo Fletes, I. and Cruz Rodríguez, J.A. (2010). Artesanas mixtecas, estrategias de reproducción y cambio. Revista de estudios de género. Revista de estudios de género: La Ventana 4(31), 101-138.

Rowlands, J. (1997) Questioning empowerment: Working with women in Honduras. Oxfam, Oxford, United Kingdom.

Schneider, L. (2001). Tradición y fantasía del barro. Artes de México 30, 30-45.

SECTUR-COLMEX (2011). Análisis Económico del Mercado Laboral en el Sector Turístico: Hacia una Política Pública para la Igualdad entre Mujeres y Hombres. SECTUR, El Colegio de México, Mexico City, Mexico.

Serrano-Barquín, R. (2008) Hacia un modelo teórico-metodológico para el análisis del desarrollo, la sostenibilidad y el turismo. Economía, sociedad y territorio 8(26), 313355.

Swain, M. B. (1995) Gender in tourism. Annals of Tourism Research 22(2), 247-266.

Tucker, H. and Boonabaana, B. (2012) A critical analysis of tourism, gender and poverty reduction. Journal of Sustainable Tourism 20(3), 437-455.

Vizcaino-Suárez, L.P., Serrano-Barquín, R., Cruz-Jiménez, G. and Pastor-Alfonso, M.J. (2014). El género en la investigación y las políticas turísticas en México. Available at: $\quad$ http://www.aecit.org/el-genero-en-la-investigacion-y-las-politicas-turisticas-enmexic/congress-papers/67/ (accessed 15 May 2017). 